\title{
Biological Properties
}

\section{of Regenerated Silk Fibroin Films}

Dol: $10.17691 / \mathrm{stm} 2015.7 .3 .01$

Received March 4, 2015

L.A. Safonova, Clinical Research Assistant';

M.M. Bobrova, Clinical Research Assistant ${ }^{1}$;

O.I. Agapova, Researcher, Bionanotechnology Laboratory ${ }^{1}$;

M.S. Kotliarova, Student, Bioengineering Department, Biological Faculty2;

A.Yu. Arkhipova, Junior Researcher, Confocal Microscopy Laboratory, Biological Faculty²;

M.M. Moisenovich, PhD, Head of Confocal Microscopy Laboratory2;

I.I. Agapov, DSc, Professor, Head of Bionanotechnology Laboratory

${ }^{1}$ Academician V.I. Shumakov Federal Research Center of Transplantology and Artificial Organs, Ministry of Health of the Russian Federation, 1 Schukinskaya St., Moscow, 123182, Russian Federation;

${ }^{2}$ Lomonosov Moscow State University, 1 Leninskiye Gory, Moscow, 119991, Russian Federation

The aim of the investigation was to study the biological and mechanical properties of silk fibroin films and composite silk fibroin films containing $30 \%$ collagen by weight.

Materials and Methods. All films were prepared by casting method using water and formic acid as solvents. Scanning electron microscopy and atomic force microscopy were applied. Human hepatoblastoma cell line Hep- $\mathrm{G}_{2}$ was used to test film compatibility.

Results. We studied surface roughness degree of the obtained films. Water-based films were found to have permeability for low molecular weight substances. Tensile strength and elasticity indices were measured for all types of films. Collagen added to film composition was revealed to have no significant effect on tensile strength, though it increased film elasticity. We studied the degradation of films. Collagen was shown to have no significant impact on film degradation rate both in phosphate-buffer saline and oxidizing media. We demonstrated with an example of cell line Hep- $\mathrm{G}_{2}$ that water-based films exhibit higher proliferative activity.

Conclusion. Silk fibroin water solution has the best properties to develop films for tissue engineering.

Key words: silk fibroin; collagen; biodegradable films.

The lack of donor organs for transplantations is one of urgent problems. Artificial organs containing matrix and cellular components can solve the problem.

Functional activity of the created product depends on proliferative activity of the cell it contains. However, the choice of the material used for a scaffold of an artificial organ is of great importance, too. The material is to simulate the properties of native extracellular matrix and perform its functions: determine physical properties of tissues, provide cell adhesion, proliferation, differentiation and migration. Currently, both synthetic materials and naturally occurring materials are considered for this purpose [1-3].

One of universal materials used as a scaffold component is silk fibroin of silkworm Bombyx mori.
Fibroin refers to fibrillar proteins and is characterized by a great number of repetitions in its primary structure. Such structure causes homogeneity of fibroin secondary structure presenting antiparallel $\beta$-layers with hydrogen bonds. Amorphous protein parts form $\alpha$-helixes, their proportion increasing in protein hydration. In tertiary structure of fibroin there are two chains: a heavy chain with molecular weight of $390 \mathrm{kDa}$ and a light chain, $26 \mathrm{kDa}$, their ratio being $1: 1$, the chains having disulphide bonds [4]. Changing a part of $\beta$-layers in the structure one can control mechanical properties of a product and biodegradation rate [5]. Slow silk fibroin biodegradation can be an advantage when used in tissue engineering in cases when a long period of time is required for cell proliferation and differentiation in an implant [6].

For contacts: Safonova Liubov Alexandrovna, e-mail: saf.lyubov.msu@gmail.com 
Fibroin structure has a great number of free chemical groups, which can be modified or used to create conjugates with other compounds [7], as well as composite materials with advanced properties $[8,9]$.

Thus, fibroin exhibits properties permitting to use it for fabricating different products: coatings, films, tubes, porous matrices, micro- and nanoparticles, gels, and use it in tissue engineering as an independent material, and a part of composites.

The aim of the investigation was to study the mechanical and biological properties of silk fibroin (silkworm B. mori) films and composite silk fibroin films containing $30 \%$ collagen using different solvents.

\section{Materials and Methods}

Silk fibroin preparation. Silk fibroin was taken from silkworm B. mori cocoon. During the first stage cocoons were cleaned from sericine. $1 \mathrm{~g}$ of cocoons was waterbath boiled in $500 \mathrm{ml}$ bidistilled water, with $1,260 \mathrm{mg}$ sodium carbonate added, for $40 \mathrm{~min}$ followed by washing in $3,600 \mathrm{ml}$ distilled water, boiling in $500 \mathrm{ml}$ bidistilled water for $30 \mathrm{~min}$, and washing in $3,600 \mathrm{ml}$ distilled water. The last procedure was repeated 3 times. Prepared silk fibroin was dried at room temperature.

Silk fibroin water solution preparation. To prepare water fibroin solution, to $130 \mathrm{mg}$ of washed silk we added the solution containing $389 \mathrm{mg} \mathrm{CaCl}, 388 \mu \mathrm{l}$ $\mathrm{C}_{2} \mathrm{H}_{5} \mathrm{OH}$, and $544 \mu \mathrm{l} \mathrm{H}_{2} \mathrm{O}$, per $1 \mathrm{ml}$ solution. The mixture was water-bath heated for $5 \mathrm{~h}$ until silk fully dissolved. The solution obtained was centrifuged for $7 \mathrm{~min}$ at $12,100 \mathrm{~g}$. Supernatant was dialyzed against $500 \mathrm{ml}$ of bidistilled water, in total, there were 5 dialysis changes for $30 \mathrm{~min}$. Fibroin solution was centrifuged for $7 \mathrm{~min}$ at $12,100 \mathrm{~g}$, fibroin concentration being determined spectrophotometrically at wavelength $280 \mathrm{~nm}$, molar extinction coefficient being $473,480 \quad \mathrm{M}^{-1} \mathrm{~cm}^{-1}$ that corresponds to a theoretically calculated extinction coefficient according to amino acid sequence of silk fibroin heavy chain (UniProt No.P05790).

Water collagen solution preparation. Collagen solution in acetic acid was obtained from rat tails. Solution was centrifuged [10] within $20 \mathrm{~min}$ at $5,000 \mathrm{~g}$. Supernatant was dialyzed against a liter of bidistilled water at room temperature, there were 5 dialysis changes every hour. The concentration of the obtained solution was $9 \mathrm{mg} / \mathrm{ml}$, the solution containing from 60 to $85 \%$ collagen, $60 \%$ accounting for type I collagen [11].

Preparation of silk fibroin solution in formic acid. A weighed portion of washed silk was dissolved in formic acid, in an amount of $20 \mathrm{mg} / \mathrm{ml}$ when water-bath heated to $40^{\circ} \mathrm{C}$ within $30 \mathrm{~min}$. The obtained solution was centrifuged for $5 \mathrm{~min}$ at $12,100 \mathrm{~g}$.

Fabrication of films made of silk fibroin and fibroincollagen composition. Casting technique was used to fabricate the films. To obtain a film, $1 \mathrm{~cm}$ in diameter, $100 \mu \mathrm{l}$ of solution was applied on the surface of polished teflon and dried within two days at room temperature. Total protein concentration in solution for film fabrication was $20 \mathrm{mg} / \mathrm{ml}$, collagen content in composite films was $30 \%$ by weight. Films were taken of teflon surface using scalpel following their incubation in $96 \%$ alcohol for $15 \mathrm{~min}$, and stored in $96 \%$ alcohol at $4^{\circ} \mathrm{C}$.

Analysis of film structure by scanning electron microscopy. Film samples were fixed by glutaric dialdehyde, dehydrated by increasing ethanol concentrations, and put in acetone. Then the samples were dried in critical point of carbon dioxide $\left(\mathrm{T}=31^{\circ} \mathrm{C}\right.$, $\mathrm{p}=72.8 \mathrm{~kg} / \mathrm{cm}^{2}$ ) using HCP-2 (Hitachi Ltd., Japan). Dried samples were covered by a gold layer, $20 \mathrm{~nm}$ thick, inside argon atmosphere at ion current $6 \mathrm{~mA}$ and pressure $0.1 \mathrm{~mm} \mathrm{Hg}$ using IB-3 Ion Coater (Eiko Engineering, Japan) followed by the analysis using scanning electron microscope Camscan S2 (Cambridge Instruments, Great Britain). Microscope resolution is $10 \mathrm{~nm}$, operating voltage being $20 \mathrm{kV}$. Images were acquired using MicroCapture program.

Film surface analysis by atomic force microscopy. Film samples were bi-adhesive scotch taped. After drying a sample on scotch was placed on the platform of Solver P47-PRO (NT-MDT, Russia) and scanned in a tapping mode, scanning frequency being $0.3-0.4 \mathrm{~Hz}$ and amplitude, 20-40 nm using a cantilever NSC15/AL BS with resonance frequency $265-410 \mathrm{kHz}$ and force constant 20-80 N/m (MikroMasch, USA). The scanned area was $11.324 \times 11.324 \mu \mathrm{m}$. Nova program was used to capture images, process them, design sections and three-dimensional images.

Surface roughness was assessed using Nova program, by Roughness Analysis function, which enables to calculate mean roughness value in nanometers for one scanning line.

Film porosity assessment. The porosity of films was assessed by their permeability for two stains: bromphenol blue $(\mathrm{M}=691.9 \mathrm{~g} / \mathrm{mol})$ and trypan blue $(\mathrm{M}=872.88 \mathrm{~g} / \mathrm{mol})$. For this purpose, we applied $5 \mu \mathrm{l}$ of solution on a wet film surface, and estimated visually the amount of stain passed through a film to filter paper per $1 \mathrm{~min}$.

Analysis of mechanical properties of silk fibroin films. Mechanical properties of films were studied using a tensile-testing machine Zwick/Roell BZ 2.5/TN1S (Zwick Roell, Germany). Film samples, $4 \mathrm{~cm}$ long and $5 \mathrm{~mm}$ width, were placed in the clips of the device. Preloading was $0.05 \mathrm{~N}$. The samples were tested by tension at a speed $50 \mathrm{~mm} / \mathrm{min}$. Two parameters were measured: tensile strength, $\mathrm{MPa}$, and elasticity or extension, in percentage of the original sample length. The obtained curves of tensile against extension were processed using a program TestXpert (Zwick Roell, Germany).

In vitro degradation test of films. We studied film degradation in accordance with GOST 10993-13-2009 "The study of a biological effect of medical products". As an oxidizing reagent we used Fenton reagent containing $100 \mu \mathrm{M} \mathrm{FeSO}_{4}$ and $1 \mathrm{mM} \mathrm{H}_{2} \mathrm{O}_{2}$. We changed oxidizing reagent solution every 3 days. Phosphate-buffered saline (PBS), $\mathrm{pH}=7.4$, was used as a control. The samples 
were incubated in tenfold solution volume, with weight being measured every 7 days for a 28 days.

The analysis of human hepatocarcinoma cell line Hep- $G_{2}$ proliferative activity on films of different composition. To study proliferative activity, the films were fastened to the surface wall of a 96-well plate by means of $5 \%$ gelatin aqueous solution. Culture plastic was used as a control. Before test a plate was sterilized: it was treated with $70 \%$ alcohol for $30 \mathrm{~min}$ and ultraviolet within $30 \mathrm{~min}$. Sterile PBS was put into wells for $15 \mathrm{~min}$, and then sterile $0.9 \% \mathrm{NaCl}$ solution - for $30 \mathrm{~min}$. Further, the plate walls were put $300 \mu$ of incubation medium (DMEM) with added $20 \mathrm{mmol} / \mathrm{ml}$ HEPES, 10\% fetal calf serum, $40 \mu \mathrm{g} / \mathrm{ml}$ gentamicin, and incubated for $15 \mathrm{~min}$. Human hepatocarcinoma cell line suspension, with concentration $4.2 \cdot 10^{6} \mathrm{cell} / \mathrm{ml}$ in incubation medium was transferred in 96-well plates, $200 \mu \mathrm{l}$ per a well. The

Table 1

The composition of $B$. mori silkworm fibroin based film samples

\begin{tabular}{cl}
\hline $\begin{array}{c}\text { Film } \\
\text { samples }\end{array}$ & \multicolumn{1}{c}{ Sample composition } \\
\hline 1 & Fibroin water solution \\
\hline 2 & Fibroin water solution containing $30 \%$ collagen by weight \\
\hline 3 & Fibroin solution in formic acid \\
\hline 4 & Fibroin solution in formic acid containing $30 \%$ collagen by weight \\
\hline
\end{tabular}

cells were incubated in an incubator at $37^{\circ} \mathrm{C}, 5 \% \mathrm{CO}_{2}$ for 9 days.

Proliferative activity was assessed by MTT assay on days 3,6 and 9 of the experiment. For this purpose, each well was added $50 \mu \mathrm{l}$ of 3-[4,5-dimethylthiazole-2-yl]-2,5diphenyltetrazolium bromide followed by incubation in an incubator at $37^{\circ} \mathrm{C}$, with $5 \% \mathrm{CO}_{2}$ content, for 3-4 h until precipitation of formazan crystals. Then the plate was centrifuged within $5 \mathrm{~min}$ at 1,500 rpm. Supernatant was removed; formazan recipitate was dissolved in DMSO, optical density of the solution being measured at $540 \mathrm{~nm}$ wavelength.

Data processing. The data were statistically processed using variance analysis, the significance level was equal to $p=0.05$.

Results and Discussion. For the first time ever we compared the biological and mechanical properties of films fabricated using different solvents. We obtained 4 types of films based on silk fibroin of silkworm B. mori (Table 1). The films were transparent, $50 \mu \mathrm{m}$ thick.

To improve biocompatibility of films, a composite supplement (collagen) was added to the product. Collagen was decided upon since it is the most common protein of extracellular matrix, and has in its structure RGD-sequence, to which the receptors on cell membrane are affine.
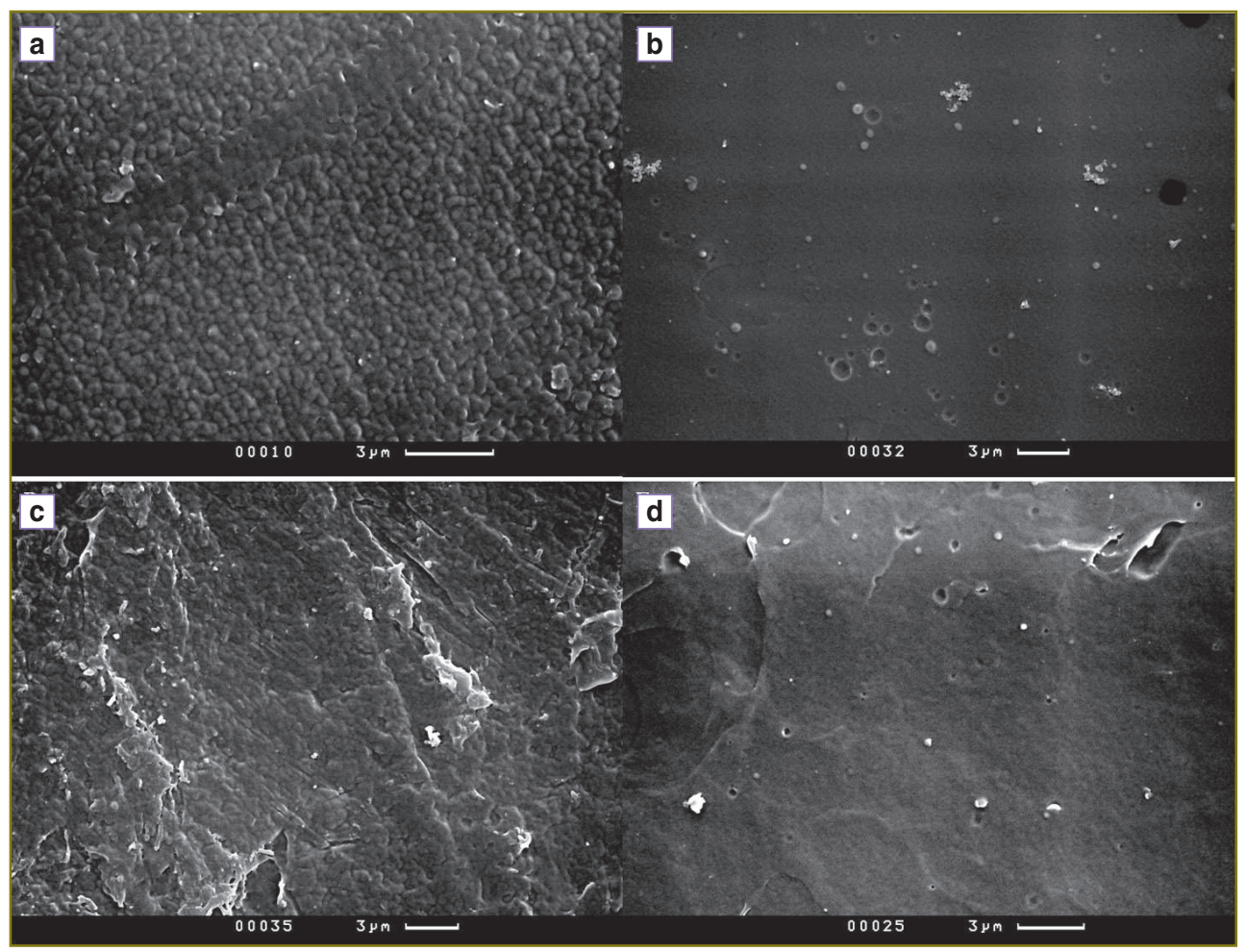

Figure 1. Scanning electron microscopic images of film surface. The films were fabricated by casting on the surface of polished teflon, and based on silk fibroin water solution (a), silk fibroin water solution with collagen (b), fibroin solution in formic acid (c), fibroin solution with collagen in formic acid (d) 
Table 2

Data on mean surface roughness of films of different composition (standard deviation values are shown for six independent measurements)

\begin{tabular}{lc}
\hline \multicolumn{1}{|c}{ Composition of films tested } & Mean surface roughness of films (nm) \\
\hline Fibroin water solution & $36.50 \pm 10.64$ \\
\hline Fibroin water solution containing 30\% collagen by weight & $47.77 \pm 11.33$ \\
\hline Fibroin solution in formic acid & $81.86 \pm 12.10$ \\
\hline Fibroin solution in formic acid containing 30\% collagen by weight & $78.76 \pm 13.44$ \\
\hline
\end{tabular}

Table 3

Experimental results for the evaluation of permeability of films of different composition

\begin{tabular}{lcc}
\hline \multicolumn{1}{c}{ Composition of films tested } & \multicolumn{2}{c}{ Stain used } \\
\cline { 2 - 3 } & $\begin{array}{c}\text { Bromphenol blue } \\
(\mathrm{M}=\mathbf{6 9 1 . 9} \mathrm{Da})\end{array}$ & $\begin{array}{c}\text { Trypan blue } \\
(\mathrm{M}=\mathbf{8 7 2 . 8 8} \mathrm{Da})\end{array}$ \\
\hline Fibroin water solution & +++ & +++ \\
\hline Fibroin water solution containing 30\% collagen by weight & +++ & + \\
\hline Fibroin solution in formic acid & 0 & 0 \\
\hline Fibroin solution in formic acid containing 30\% collagen by weight & ++ & 0 \\
\hline
\end{tabular}

N o t e. 0 : stain doesn't pass through a film; + and ++: stain passes partially through a film; +++: stain passes completely through a film.

Table 4

Data on tensile strength and elasticity of films of different composition (standard deviation values are shown for five independent measurements)

\begin{tabular}{lcc}
\hline \multicolumn{1}{c}{ Composition of film tested } & Tensile strength (MPa) & Elasticity (\%) \\
\hline Fibroin water solution & $5.22 \pm 1.95$ & $80.25 \pm 20.52$ \\
\hline $\begin{array}{l}\text { Fibroin water solution containing } 30 \% \text { collagen } \\
\text { by weight }\end{array}$ & $1.38 \pm 0.12$ & $73.0 \pm 8.49$ \\
\hline $\begin{array}{l}\text { Fibroin solution in formic acid } \\
\text { Fibroin solution in formic acid containing 30\% } \\
\text { collagen by weight }\end{array}$ & $3.09 \pm 0.51$ & $30.0 \pm 8.41$ \\
\hline
\end{tabular}

We studied film surface structure by scanning electron microscopy. Film surface was found to have micro- and nanorelief in the form of roughness (Figure 1).

Roughness determines cell adhesion, as well as it increases the surface area available for adhesion. Substrate roughness appears to have an optimal level. A substrate is likely to have an optimal level of roughness, which is peculiar for different cell cultures [12]. Roughness was studied using atomic force microscopy. Roughness was $70-90 \mathrm{~nm}$ for films fabricated on the basis of polymers in formic acid, and $30-50 \mathrm{~nm}$ for those made of water polymer solution (Table 2). Collagen as part of film composition has no significant effect on roughness.

Qualitative analysis of film permeability showed water-based films to have better permeability compared to those based on polymers in formic acid (Table 3). Permeability characterizes the capability of a product to let pass biologically active substances necessary for tissue proper development.

Products designed for regenerative surgery should be mechanically strong, since brittle and/or fragile appliances fail in implantation. Elasticity of the material used should comply with the elasticity of native tissue damaged. Films including collagen have significantly lower tensile strength indices than those made of silk fibroin solutions (Table 4). Collagen added to film composition has slight effect on film elasticity. In addition to high elasticity, silk fibroin films exhibits the highest mechanical strength.

We studied film degradation in two media: neutral and oxidizing. PBS was used as a neutral medium, since its composition is similar to body internal environment. Under such conditions the mass of samples changed in the range of $7 \%$ for 28 days. Fenton reagent was used as an oxidizing medium, since it simulates cell-mediated 


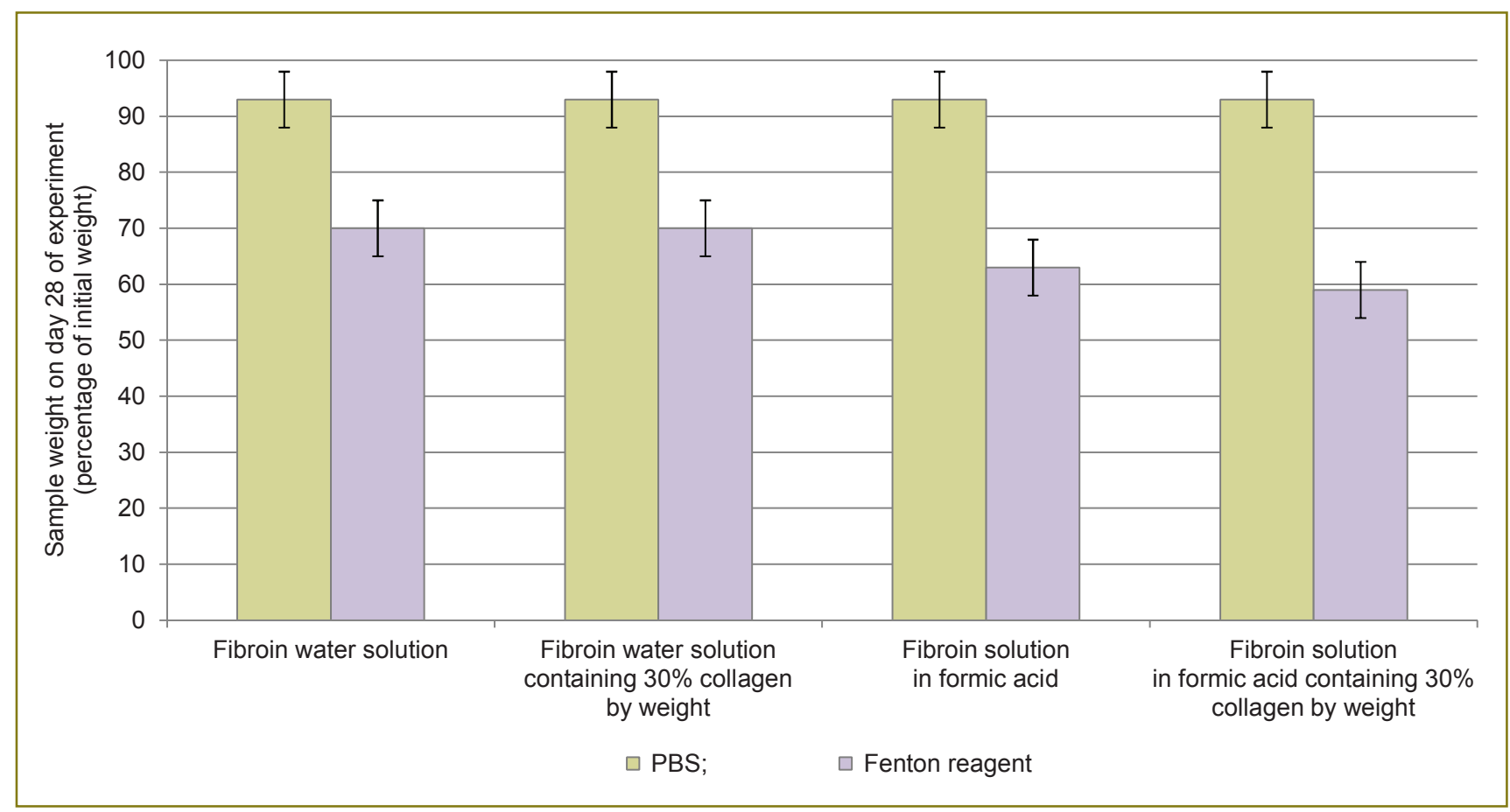

Figure 2. Variation of sample weight in percentage from the initial weight in PBS and Fenton reagent on day 28 of the experiment. Standard deviation values are shown for three independent measurements

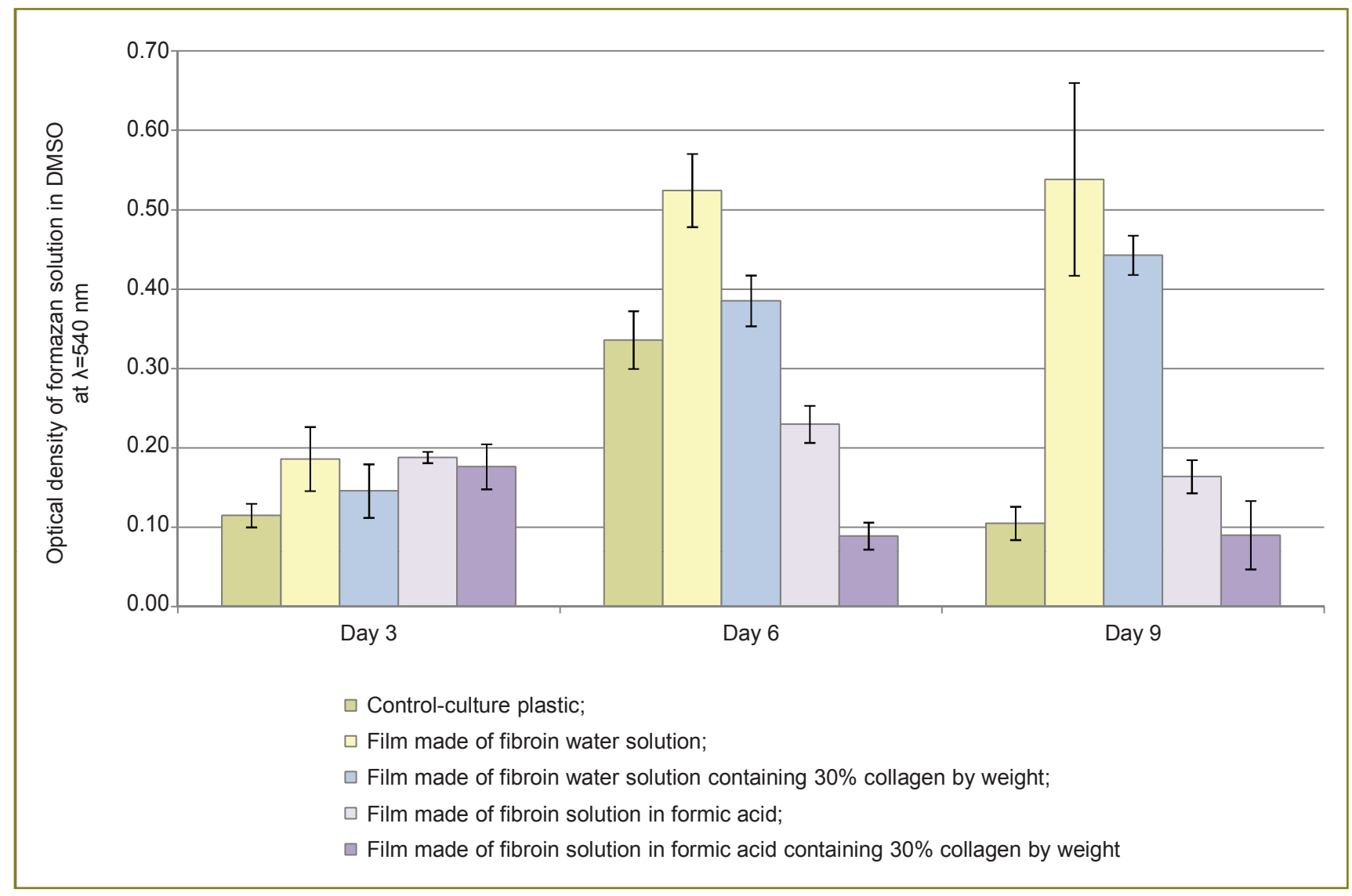

Figure 3. Proliferative activity of Hep- $\mathrm{G}_{2}$ cell line on films of different composition on days 3,6 and 9 of the experiment. Standard deviation values are shown for five independent measurements 
response reactions on an implant due to hydroxyl radicals formed in the course of Fenton reaction and interactive with a sample. In oxidizing media the mass of samples decreased by $34 \%$ on average (Figure 2).

In oxidizing media, the degradation of films based on water fibroin solution with collagen added was accompanied by sharp deterioration of mechanical properties, and consequently, the product's inability to hold shape, while other films held their shape by week 4 of the experiment. The analysis of findings showed collagen to have no significant effect on film degradation rate both in neutral and oxidizing media.

Proliferative cell activity test was carried out on human hepatocarcinoma cell line Hep- $\mathrm{G}_{2}$. The cells of this line have integrin receptors [13] affine to RGD sequence, which is present in collagen structure.

Silk fibroin compositions, as well as consisiting of its composites with collagen, gelatin, chitosan and other materials, are used in tissue engineering as matrix for culturing human hepatocarcinoma cells. Threedimensional porous matrix of silk fibroin with chitosan serves as an example [14]. Proliferative activity of $\mathrm{Hep}-\mathrm{G}_{2}$ cells on such matrices was comparable with positive control that makes it possible to consider it to be suitable for liver tissue engineering.

The highest proliferative cell activity was observed on silk fibroin films (Figure 3). It increased within the test on films based on water fibroin solution with collagen added, and was consistent with that of the cells on films made of aqueous silk fibroin. It can be due to the fact that collagen as a part of composite fails to provide proliferative activity growth due to cell receptor shielding by fibroin molecules of collagen RGDsequence. However, in literature there are still examples of successful use of collagen as a composite additive to improve proliferative activity of Hep- $\mathrm{G}_{2}$ culture cells, it being a part of both three-dimensional matrices [15], and films [16].

The lowest proliferative activity was observed on films based on polymer solutions in formic acid.

According to the findings we can conclude that silk fibroin water solution is the most appropriate for fabricating films with optimal properties for tissue engineering.

Conclusion. The study of the characteristics of regenerated silk fibroin films that can potentially have an impact on cell proliferative activity and possible application in tissue engineering (the following characteristics were chosen: permeability, surface roughness, mechanical properties, degradation rate, as well as the ability to provide adhesion and proliferation of eukaryotic cells) showed that water polymer based films are characterized by permeability for low molecular weight substances, high mechanical strength and elasticity. Surface roughness was observed on all types of fabricated films and depends on a solvent used. All films were found to maintain proliferative activity of cells.
Collagen added to a film composition appeared to have no effect on cell proliferative activity, though it changes mechanical properties of films.

Acknowledgements. The authors thank Svetlana Petrovna Novikova, Head of the Laboratory of Chemistry and Technology of Materials for Cardiovascular Surgery, Bakoulev Center for Cardiovascular Surgery, Russian Academy of Medical Sciences, and Regina Rushanovna Salokhedinova, Researcher, for research assistance for the experiments for mechanical measurements.

Study Funding. The study was supported by Ministry of Education and Science of the Russian Federation under Federal Targeted Program "Research and development in priority directions of Russian technological system during 2014-2020" according to the Grant Agreement dated June, 17, 2014 No.14.604.21.0017 "New medications based on biodegradable materials with immobilized peptide agonists of proteinase activated receptors to treat traumatic and ischemic tissue injuries", unique agreement identifier RFMEFI60414X0017.

Conflicts of Interest. The authors have no conflicts of interest to declare.

\section{References}

1. Moisenovich M.M., Pustovalova O., Shackelford J., Vasiljeva T.V., Druzhinina T.V., Kamenchuk Y.A., Guzeev V.V., Sokolova O.S., Bogush V.G., Debabov V.G., Kirpichnikov M.P., Agapov I.I. Tissue regeneration in vivo within recombinant spidroin 1 scaffolds. Biomaterials 2012; 33(15): 3887-3898, http://dx.doi.org/10.1016/j.biomaterials.2012.02.013.

2. Bonartsev A., Yakovlev S., Boskhomdzhiev A., Zharkova I., Bagrov D., Myshkina V., Mahina T., Kharitonova E., Samsonova O., Zernov A., Zhuikov V., Efremov Y., Voinova V., Bonartseva G., Shaitan K. The terpolymer produced by Azotobacter chroococcum 7B: effect of surface properties on cell attachment. PLoS One 2013; 8(2): e57200, http://dx.doi. org/10.1371/journal.pone.0057200.

3. Moisenovich M.M., Pustovalova O.L., Arhipova A.Y., Vasiljeva T.V., Sokolova O.S., Bogush V.G., Debabov V.G., Sevastianov V.I., Kirpichnikov M.P., Agapov I.I. In vitro and in vivo biocompatibility studies of a recombinant analogue of spidroin 1 scaffolds. J Biomed Mater Res A 2011; 96(1): 125131, http://dx.doi.org/10.1002/jbm.a.32968.

4. He Y.-H., Zhang N.-N., Li W.-F., Jia N., Chen B.-Y., Zhou K., Zhang J., Chen Y., Zhou C.-Z. N-terminal domain of Bombyx mori fibroin mediates the assembly of silk in response to $\mathrm{pH}$ decrease. J Mol Biol 2012; 418(3-4): 197-207, http:// dx.doi.org/10.1016/j.jmb.2012.02.040.

5. Kasoju N., Bora U. Silk fibroin based biomimetic artificial extracellular matrix for hepatic tissue engineering applications. Biomed Mater 2012; 7(4): 045004, http://dx.doi. org/10.1088/1748-6041/7/4/045004.

6. Hu Y., Zhang Q., You R., Wang L., Li M. The relationship between secondary structure and biodegradation behavior of silk fibroin scaffolds. Advances in Materials Science and Engineering 2012; 2012: 185905, http://dx.doi. org/10.1155/2012/185905.

7. Baran E.T., Tuzlakoğlu K., Mano J.F., Reis R.L. Enzymatic degradation behavior and cytocompatibility of silk fibroin-starch-chitosan conjugate membranes. Materials 
Science and Engineering 2012; 32(6): 1314-1322, http://dx.doi. org/10.1016/j.msec.2012.02.015.

8. Moisenovich M.M., Arkhipova A.Y., Orlova A.A., Drutskaya M.S., Volkova S.V., Zacharov S.E., Agapov I.I., Kirpichnikov M.P. Composite scaffolds containing silk fibroin, gelatin, and hydroxyapatite for bone tissue regeneration and $3 \mathrm{D}$ cellc. Acta Naturae 2014; 6(1): 96-101.

9. Agapov I.I., Moisenovich M.M., Druzhinina T.V., Kamenchuk Y.A., Trofimov K.V., Vasilyeva T.V., Konkov A.S., Arhipova A.Y., Sokolova O.S., Guzeev V.V., Kirpichnikov M.P. Biocomposite scaffolds containing regenerated silk fibroin and nanohydroxyapatite for bone tissue regeneration. Dokl Biochem Biophys 2011; 440: 228-230, http://dx.doi.org/10.1134/ S1607672911050103.

10. Chandrakasan G., Torchia D.A., Piez K.A. Preparation of intact monomeric collagen from rat tail tendon and skin and the structure of the nonhelical ends in solution. J Biol Chem 1976; 251(19): 6062-6067.

11. Kjaer M. Role of extracellular matrix in adaptation of tendon and skeletal muscle to mechanical loading. Physiol Rev 2004; 84(2): 649-698, http://dx.doi.org/10.1152/ physrev.00031.2003.
12. Zhang Q., Zhao Y., Yan S., Yang Y., Zhao H., Li M., Lu S., Kaplan D.L. Preparation of uniaxial multichannel silk fibroin scaffolds for guiding primary neurons. Acta Biomaterialia 2012; 8(7): 2628-2638, http://dx.doi.org/10.1016/ j.actbio.2012.03.033.

13. Rosenow F., Ossig R., Thormeyer D., Gasmann P., Schlüter K., Brunner G., Haier J., Eble J.A. Integrins as antimetastatic targets of RGD-independent snake venom components in liver metastasis. Neoplasia 2008; 10(2): 168-176.

14. She Z., Jin C., Huang Z., Zhang B., Feng Q., Xu Y. Silk fibroin/chitosan scaffold: preparation, characterization, and culture with HepG2 cell. J Mater Sci Mater Med 2008; 19(12): 3545-3553, http://dx.doi.org/10.1007/s10856-008-3526-y.

15. Lv Q., Feng Q., Hu K., Cui F. Three-dimensional fibroin/ collagen scaffolds derived from aqueous solution and the use for HepG2 culture. Polymer 2005; 46(26): 12662-12669, http:// dx.doi.org/10.1016/j.polymer.2005.10.137.

16. Hu K., Lv Q., Cui F.Z., Feng Q.L., Kong X.D., Wang H.L., Huang L.Y., Li T. Biocompatible fibroin blended films with recombinant human-like collagen for hepatic tissue engineering. Journal Bioactive and Compatible Polymers 2006; 21(1): 23-37, http://dx.doi.org/10.1177/0883911506060455. 